\title{
Should Surgical Burs Be Used as Single-Use Devices to Avoid Cross Infection? A Case-Control Study
}

\author{
Badr A. Al-Jandan ${ }^{\text {a }}$ Mohamed Gafar Ahmed ${ }^{\text {b }}$ Khalifa Sulaiman Al-Khalifa ${ }^{c}$ \\ Imran Farooq ${ }^{\mathrm{a}}$ \\ a Department of Biomedical Dental Sciences, College of Dentistry, ${ }^{b}$ Department of Oral and Maxillofacial Surgery, \\ King Fahd Hospital of the University, and 'Department of Preventive Dental Sciences, College of Dentistry, \\ University of Dammam, Dammam, Saudi Arabia
}

\section{Key Words}

Cross infection - Dental burs · Dental instruments .

Resterilization · Sterilization

\begin{abstract}
Objective: The purpose of this study was to evaluate and compare the rate of bacterial contamination of reused and new unused burs after different sterilization sessions. Materials and Methods: The test group consisted of 40 used fissure burs, and the control group of 40 unused new fissure burs (total $n=80$ ). The burs from both groups were precleaned according to standard protocols and then subjected to two sterilization sessions (high- and low-steam pressure autoclaving). After each sterilization session, the burs were transferred into incubation tubes which contained thioglycollate culture medium and were monitored daily for a period of $48 \mathrm{~h}$ to detect any bacterial growth. Data were collected and statistical analysis was done using Fisher's exact test. Results: Of the 40 burs of the test group, 2 burs (5\%) showed positive bacterial growth, whereas no bur from the control group showed any sign of bacterial growth after high-pressure autoclaving. The colony structure and Gram staining were compatible with the growth of Staphylococcus epidermis. After a
\end{abstract}

second sterilization session at low-pressure steam autoclaving, no bacterial growth was observed for the test group, but 1 bur (2.5\%) from the control group showed bacterial growth and Gram-positive staining matched well with the growth of Brevibacterium species. Conclusions: The new and unused burs were $100 \%$ sterile after high-pressure steam autoclaving, whereas $5 \%$ of the reused burs appeared positive with bacterial contamination. After low-pressure steam autoclaving, reused burs were $100 \%$ sterile, but 1 new bur demonstrated bacterial contamination.

(c) 2015 S. Karger AG, Basel

\section{Introduction}

The oral cavity is home to a wide variety of microorganisms, and adequate prevention of cross infection during dental procedures is vital [1]. Infection can be transmitted through dentists and dental staff to patients, from patients to the dental team, and from one patient to another via contamination of instruments [2]. Guidelines regarding the sterilization of medical instruments are provided by various international bodies. The International Organization for Standardization provides guidelines for

\begin{tabular}{|c|c|}
\hline KARGER & $\begin{array}{l}\text { (C) } 2015 \text { S. Karger AG, Basel } \\
1011-7571 / 15 / 0252-0159 \$ 39.50 / 0\end{array}$ \\
\hline $\begin{array}{l}\text { E-Mail karger@karger.con } \\
\text { www.karger.com/mpp }\end{array}$ & $\begin{array}{l}\text { This is an Open Access article licensed under the terms of the } \\
\text { Creative Commons Attribution-NonCommercial } 3.0 \text { Un- } \\
\text { ported license (CC BY-NC) (www.karger.com/OA-license), } \\
\text { applicable to the online version of the article only. Distribu- } \\
\text { tion permitted for non-commercial purposes only. }\end{array}$ \\
\hline
\end{tabular}

Badr A. Al-Jandan

Department of Biomedical Dental Sciences

College of Dentistry, University of Dammam

Dammam 31441 (Saudi Arabia)

E-Mail baljandan@uod.edu.sa 
Table 1. Details on bur sterilization in the two study groups

\begin{tabular}{|c|c|c|c|c|}
\hline Sterilization session & $\begin{array}{l}\text { Conditioning } \\
\text { duration }\end{array}$ & $\begin{array}{l}\text { Sterilization } \\
\text { cycle duration }\end{array}$ & $\begin{array}{l}\text { Drying } \\
\text { duration }\end{array}$ & $\begin{array}{l}\text { Temperature } \\
\text { range, }{ }^{\circ} \mathrm{C}\end{array}$ \\
\hline High-pressure steam autoclaving & $10 \min 23 \mathrm{~s}$ & $4 \mathrm{~min}$ & $11 \mathrm{~min} 40 \mathrm{~s}$ & $132.1-134.3$ \\
\hline Low-pressure steam autoclaving & $60 \min$ & $30 \mathrm{~min}$ & $16 \min 41 \mathrm{~s}$ & $122.5-127.7$ \\
\hline
\end{tabular}

the development, validation and control of the moist heat sterilization procedure for medical instruments/devices [3]. The British Dental Association recommends that any reusable instrument which comes into contact with oral fluids must be comprehensively cleaned and sterilized before another use [4]. Both of these infection control processes (cleaning and sterilization) are of equal importance. Cleaning warrants that the instrument is free from any retained debris, the presence of which can compromise the complete sterilization process [5], whereas effective sterilization ensures the destruction of all microorganisms including their spores [6]. Ineffective sterilization of dental instruments could aid in the transmission of many lifethreatening viruses, including hepatitis virus (HBV and $\mathrm{HCV}$ ), and human immunodeficiency virus [7].

Resterilization is defined as 'repeated application of a terminal process designed to remove or destroy all viable forms of microbial life, including bacterial spores, to an acceptable sterility assurance level' [8]. Considering the financial issues, reusing of instruments is practiced by the majority of dentists and hospitals worldwide [9] and is also permitted by many regulatory bodies, including the American Dental Association [10]. A single-use device is any instrument that comes in a packaging with instructions that it should not be reused and should be disposed after first use from the manufacturer [11].

Although dental instruments are routinely sterilized in hospital settings and dental practices, there is still a deficit of studies reporting the rate of bacterial contamination of dental instruments. Therefore, the purpose of this study was to evaluate and compare the rate of bacterial contamination of reused fissure burs with new unused burs used in a hospital-based dental setting.

\section{Materials and Methods}

The study took place at the Oral and Maxillofacial Surgery Clinic, King Fahd Hospital of the University, University of Dammam, Dammam, Saudi Arabia. Ethical approval was obtained for this study from the Institutional Review Board. The test group con- sisted of 40 (No. 701) carbide fissure burs which had been previously used for various surgical procedures, and the control group consisted of 40 (No. 701) carbide unused new fissure burs (total $\mathrm{n}=80)$.

\section{Cleaning of the Burs before Sterilization}

The burs from both groups were soaked in Prolystica ${ }^{\circledR} 2 \mathrm{X}$ Concentrate Alkaline Detergent (STERIS, USA) for $5 \mathrm{~min}$ and then rinsed with warm water for $5 \mathrm{~min}$. After rinsing, burs were cleansed for 25 min with ASEPTL-ZYME ${ }^{\mathrm{TM}}$ (Ecolab ${ }^{\circledR}$, USA) in an ultrasonic cleaner (Bransonic ${ }^{\circledR}$ 8510E-DTH; Mackay and Linn, USA).

\section{Sterilization Sessions}

After drying, the burs were packed individually into their respective labeled designated sterilization pouches. The test burs were grouped together and the control burs were also grouped together based on the intended sterilization technique, and then sent to the Department of Central Sterilization of the Hospital. Burs from the two groups were then subjected to sterilization sessions, which involved high- and low-pressure steam autoclaving. For this study, the sterilization sessions were applied only once to each group of the burs. Details on the treatments applied are summarized in table 1 for both groups.

\section{Assessment of Bacterial Growth}

After each sterilization session, burs from both groups were transferred to incubation tubes which contained thioglycollate culture medium The burs were then monitored on a daily basis for a period of $48 \mathrm{~h}$ to detect any potential growth of bacteria. Growth of bacteria was recorded daily by a microbiologist, and subculturing was performed in all positive growth media to identify the type of bacteria.

\section{Statistical Analysis}

The Statistical Package for the Social Sciences (version 19.0; SPSS Inc., Chicago, Ill., USA) was used for statistical analysis. Fisher's exact test was used to analyze any significant difference between the two groups, and the level of significance was set at $\mathrm{p}<$ 0.05 .

\section{Results}

After the first sterilization session at high-pressure steam autoclaving, 2 burs (5\%) from the test group demonstrated bacterial growth, but no bur from the control 
Table 2. Number and percentage of burs which showed positive bacterial growth along with the species found after Gram staining

\begin{tabular}{llll}
\hline Group & \multicolumn{2}{l}{ Positive burs after sterilization session } & Species \\
\cline { 2 - 3 } & $\begin{array}{l}\text { high-pressure } \\
\text { steam autoclaving }\end{array}$ & $\begin{array}{l}\text { low-pressure } \\
\text { steam autoclaving }\end{array}$ & \\
\hline Test group $(\mathrm{n}=40)$ & $2(5 \%)$ & $\begin{array}{l}0(97.5 \%) \\
1(2.5 \%)\end{array}$ & $\begin{array}{l}\text { S. epidermis } \\
\text { Brevibacterium species }\end{array}$ \\
\hline
\end{tabular}

$p=0.0124$ (Fisher's exact test). Percentages were calculated from the total number of burs for each group.

group showed any sign of bacterial growth after $48 \mathrm{~h}$. The colony structure and Gram-positive staining were compatible with the growth of Staphylococcus epidermis, and the percentage of burs showing bacterial contamination was calculated from the total number of burs in each group (table 2).

The analysis of burs after the second sterilization session at low-pressure steam autoclaving revealed no bacterial growth after $48 \mathrm{~h}$ in the test group, but 1 bur $(2.5 \%)$ from the control group showed bacterial growth. The colony structure and Gram staining matched well with the growth of Brevibacterium species (table 2). Differences observed in the two sterilization sessions were statistically significant $(\mathrm{p}=0.0124)$.

\section{Discussion}

In this study, autoclaving some of the reused burs using high-pressure stream showed bacterial growth after $48 \mathrm{~h}$ of incubation. A probable explanation could be improper handling or ineffective decontamination of burs. This finding is similar to results reported previously [12, 13], where cleaning procedures of the instruments used in a oral and maxillofacial surgery clinic showed that decontamination was not comprehensively done [12] and sterilization procedures for reused burs were not $100 \%$ effective [13]. These results indicate that if hospital sterilization procedures are not as effective as they are thought to be, then sterilization taking place in the dental practices may also not be sufficiently effective.

In the present study, the finding that 1 new and unused bur from the test group demonstrated bacterial growth after $48 \mathrm{~h}$ of low-pressure steam autoclaving was consistent with the results of a previous similar study, which found that new burs can also show bacterial contamina- tion [14]. Since the burs from the control group were never opened or used before, the presence of bacterial growth in one of the burs after the sterilization session could be attributed to the ineffective handling of these instruments. This particular finding could emphasize the need to effectively sterilize the instruments before its first use, even if the packaging states that they are sterile, to avoid the risk of cross contamination.

It is suggested that optimum cleaning protocols should be practiced to remove any debris from a used instrument, and measures should be taken to prevent contamination when the new instruments are being packaged. Such steps would not only lead towards the development of a good practice but also ensure a reduction in the spread of cross infections.

The limitations of the present study include its small sample size of burs, the same bur type used in both the groups, the same protocol of disinfection and one brand of autoclave used in this study. It should be kept in mind that modifications of these factors could lead towards different results. Future studies altering the above-mentioned factors should be performed to explore this research area further.

\section{Conclusions}

In this study, after high-pressure steam autoclaving, new unused burs were $100 \%$ sterile, whereas $5 \%$ of the reused burs showed positive bacterial contamination. When subjected to low-pressure steam autoclaving, reused burs were $100 \%$ sterile and only one new bur demonstrated bacterial contamination. Adequate steps should be taken to prevent the spread of infectious diseases that could include using dental burs as single-use devices. 


\section{Acknowledgments}

The authors gratefully acknowledge the contribution of all the staff of the King Fahd Hospital of the University for providing tremendous support towards successful completion of this study. The authors also extend their appreciation to Mr. Pio Dennis Ilano Dasal (microbiologist) for helping with sample culturing.

\section{Disclosure Statement}

The authors have no conflict of interest to disclose.

\section{References}

1 Miller CH, Tan CM, Beiswanger MA, et al: Cleaning dental instruments: measuring the effectiveness of an instrument washer/disinfector. Am J Dent 2000;13:39-43.

2 Laheij AM, Kistler JO, Belibasakis GN, et al; European Oral Microbiology Workshop (EOMW) 2011: Healthcare-associated viral and bacterial infections in dentistry. J Oral Microbiol DOI: 10.3402/jom.v4i0.17659.

3 International Organization for Standardization.https://www.iso.org/obp/ui/\#iso:std:iso:ts: 17665:-3:ed-1:v1:en (accessed Jan 22, 2015).

4 British Dental Association: Infection Control in Dentistry. Advice Sheet A12. 2002. http:// www.bda.org (accessed Jan 22, 2015).
5 Favero MS, Bond WW: Chemical disinfection of medical and surgical material; in Block SS (ed): Disinfection, Sterilization and Preservation, ed 5. Philadelphia, Lippincott Williams \& Wilkins, 2001, pp 881-917.

6 Neumann O, Feronti C, Neumann AD, et al: Compact solar autoclave based on steam generation using broadband light-harvesting nanoparticles. Proc Natl Acad Sci USA 2013; 110:11677-11681.

7 Azodo CC, Ehigiator O, Ojo MA: Occupational risks and hepatitis $\mathrm{B}$ vaccination status of dental auxiliaries in Nigeria. Med Princ Pract 2010;19:364-366.

8 Dunn D: Reprocessing single-use devices the ethical dilemma. AORN J 2002;75:989999.

-9 Smith AJ, Bagg J, Hurrell D, et al: Sterilization of re-usable instruments in general dental practice. Br Dent J 2007;203:E16.
10 American Dental Association: Sterilization and disinfection of dental instruments. 2009. http://www.ada.org/ /media/ADA/Member\%20Center/FIles/cdc_sterilization.ashx (accessed Jan 22, 2015).

11 Charatan F: Controversy erupts over reuse of 'single use' medical devices. West J Med 2000; 172:58-59.

12 Hogg NJ, Morrison AD: Resterilization of in struments used in a hospital-based oral and maxillofacial surgery clinic. J Can Dent Assoc 2005;71:179-182.

13 Morrison A, Conrod S: Dental burs and endodontic files: are routine sterilization procedures effective? Tex Dent J 2010;127:295-300.

14 Morrison A, Conrod S: Dental burs and endodontic files: are routine sterilization procedures effective? J Can Dent Assoc 2009;75:39. 